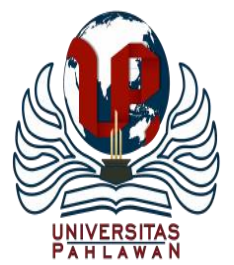

Edukatif : Jurnal Ilmu Pendidikan Volume 3 Nomor 4 Tahun 2021 Halm 2305 - 2312

EDUKATIF: JURNAL ILMU PENDIDIKAN

Research \& Learning in Education

https://edukatif.org/index.php/edukatif/index

\title{
Hubungan Konsentrasi Belajar Siswa terhadap Prestasi Belajar Peserta Didik pada Masa Pandemi Covid-19 di Sekolah Dasar
}

\author{
Riinawati \\ Universitas Islam Negeri Antasari Banjarmasin, Indonesia \\ E-mail : riinawati@uin-antasari.ac.id
}

\begin{abstract}
Abstrak
Tujuan penelitian ini yaitu untuk mengetahui ada tidaknya hubungan konsentrasi belajar dengan prestasi belajar peserta didik pada masa pandemi covid-19 di SDN Karang Mekar 4 Banjarmasin. Metode penelitian pada penelitian ini menggunakan deskripsi korelasi. Penelitian ini dilakukan di SDN Karang Mekar 4 Banjarmasin dengan siswa-siswi SDN Karang Mekar 4 Banjarmasin sebagai subjek penelitian. Dalam penelitian ini yang dijadikan objek penelitian adalah Hubungan Konsentrasi Belajar dengan Prestasi Belajar Peserta Didik pada masa Pandemi Covid-19 Di SDN Karang Mekar 4 Banjarmasin. Populasi dalam penelitian ini adalah siswa siswi SDN Karang Mekar 4 Banjarmasin. Teknik sampel yang digunakan dalam penelitian ini menggunakan purposive sampling dan sampel penelitian ini ditetapkan di kelas III di SDN Karang Mekar 4 Banjarmasin, Kelas III dengan jumlah 32 siswa. Hasil dari penelitian ini menunjukkan bahwa konsentrasi belajar sangat berhubungan erat terhadap prestasi belajar peserta didik pada masa pandemi covid-19 di Sekolah Karang Mekar 4 Banjarmasin, terbukti dengan siswa yang berkonsentrasi belajarnya cukup baik prestasi belajarnyanya lebih baik.
\end{abstract}

Kata Kunci: konsentrasi belajar, prestasi belajar, pandemi COVID-19.

\begin{abstract}
The purpose of this study was to decide whether there was a relationship between learning concentration and student achievement during the COVID-19 pandemic at SDN Karang Mekar 4 Banjarmasin. The research method in this study uses a description of the correlation. This research was conducted at SDN Karang Mekar 4 Banjarmasin with students at SDN Karang Mekar 4 Banjarmasin as research subjects. In this study, the object of research is the relationship between learning concentration and student achievement during the Covid-19 pandemic at SDN Karang Mekar 4 Banjarmasin. The population in this study were students of SDN Karang Mekar 4 Banjarmasin. The sampling technique used in this study was purposive sampling and the sample was assigned to class III at SDN Karang Mekar 4 Banjarmasin, Class III with a total of 32 students. The results of this study show that learning concentration is very closely related to student learning achievement during the covid-19 pandemic at Karang Mekar 4 School Banjarmasin, as shown by students who concentrate on studying quite well, their learning achievements are better.
\end{abstract}

Keywords: learning concentration, learning achievement, Covid-19 pandemic.

Copyright (c) 2021 Riinawati

$\triangle$ Corresponding author

Email : riinawati@uin-antasari.ac.id

DOI : https://doi.org/10.31004/edukatif.v3i4.886 
2306 Hubungan Konsentrasi Belajar Siswa terhadap Prestasi Belajar Peserta Didik pada Masa Pandemi Covid19 di Sekolah Dasar - Riinawati

DOI: https://doi.org/10.31004/edukatif.v3i4.886

\section{PENDAHULUAN}

Pendidikan merupakan suatu kegiatan yang dilakukan untuk seseorang menjadi lebih baik dari sebelumnya. Dalam Undang-Undang RI Nomor 20 Tahun 2003 tentang Sistem Pendidikan Nasional Bab I Pasal 1 (1) pendidikan didefinisikan sebagai usaha sadar untuk mewujudkan suasana belajar dan proses belajar agar peserta didik secara aktif mengembagkan potensi dirinya [1]. Education is basically a conscious effort to grow and develop the potential of human resources, especially students, which is carried out by guiding and facilitating their learning activities [2-5]. Education aims to prepare students to become positive prospective professional educators who have the task of guiding, training, building knowledge, skills, and habits in life [68]. The sustainability of education in these educational institutions is closely related to the curriculum, because current technological advances have also influenced students in their learning process [9-12]. Pedidikan dapat meningkatkan pegetahuan danketerampilan setiap orang melalui belajar (Juita, 2020).

Pengertian pendidikan secara umum adalah usaha sadar dan terencana untuk mewujudkan suasana belajar dan proses pembelajaran untuk peserta didik agar secara aktif mengembangkan potensi dirinya untuk memiliki kekuatan spiritual keagamaan, pengendalian diri, kepribadian, kecerdasan, akhlak mulia, serta keterampilan yang diperlukan dirinya, masyarakat, bangsa dan negara (Nasional, 1982).

Pendidikan juga dapat diartikan sebagai proses pembelajaran yang memungkinkan siswa untuk memahami, memahami dan membuat orang berpikir lebih kritis. Pengalaman apa pun yang berdampak pada cara orang berpikir, merasa, atau berperilaku dapat dianggap sebagai pendidikan yang sesuai dengan kebutuhan anda. Pendidikan mencakup segala upaya dan tindakan generasi tua, untuk menanamkan pengetahuan, keterampilan, dan keterampilannya kepada generasi muda, sehingga mereka dapat menjalankan fungsi kehidupannya semaksimal mungkin dalam interaksi sosial (Masalah, 2008). Konsentrasi sangat berpengaruh terhadap keberhasilan proses belajar dan mengajar, apabila seseorang mengalami kesulitan konsentrasi didalamnya, maka proses belajar tidak optimal. Hal tersebut akan membuang waktu, tenaga, dan biaya (Slameto, 2013) (B. Di et al., 2015). Ciri-ciri seseorang yang tidak konsentrasi antara lain sering bosan terhadap suatu hal, selalu berpindah tempat tidak mendengarkan ketika diajak berbicara, mengalihkan pembicaraan, sering mengobrol, dan mengganggu teman lainnya (Suntari, \& Widianah, 2012) (Balinda, Prasetyo, Julianto, Dzulqaidah, \& Salsabilah, 2014) Keberhasilan proses pembelajaran dapat dilihat dari tingkat konsentrasi siswa di dalam kelas. Konsentrasi belajar adalah pemusatan perhatian dalam proses perubahan tingkah laku, yang diwujudkan dalam penguasaan, penggunaan dan evaluasi sikap dan nilai, pengetahuan dasar dan keterampilan yang terdapat pada setiap bidang pembelajaran (Ikbal et al., 2017).

Menurut Asmani dalam Malawi (2013: 27) ada dua indikator yang dapat dijadikan sebagai tolak ukur keberhasilan proses belajar yaitu daya serap terhadap pelajaran dan perubahan perilaku siswa. Salah satu faktor yang dapat mempengaruhi rendahnya daya serap siswa adalah konsentrasi (Aviana \& Hidayah, 2015). Dilihat dari asal katanya, konsentrasi atau concentrate berarti memusatkan. Konsentrasi itu sendiri berarti pemusatan pemikiran terhadap suatu hal dengan menyampingkan semua hal lainnya yang tidak berhubungan. Dalam belajar, konsentrasi berarti pemusatan pikiran terhadap suatu mata pelajaran dengan menyampingkan semua hal lainnya yang tidak berhubungan dengan pelajaran (Slameto, 2010) (Setiani et al., 2014).

Konsentrasi belajar merupakan suatu aspek psikologis yang terkadang tidak mudah untuk diketahui oleh orang lain selain diri sendiri yang sedang belajar. Menurut Supriyo (2008:103) konsentrasi adalah pemusatan perhatian pikiran terhadap suatu hal dengan mengesampingkan semua hal lainnya yang tidak berhubungan (Andari Susilowati, 2009). Konsentrasi belajar adalah suatu hal yang sulit untuk diatasi oleh siswa, karena banyak hal yang dapat mempengaruhi konsentrasi siswa dalam belajar.Untuk dapat membantu siswa agar dapat berkonsentrasi dalam belajar dibutuhkan waktu yang cukup lama, ketelatenan guru dalam menghadapi siswa dan juga bimbingan serta perhatian guru dapat meningkatkan konsentrasi siswa dalam belajar (Navia \& Yulia, 2017). 
Faktor-faktor yang mempengaruhi konsentrasi belajar diantaranya adalah motivasi yang diperoleh, keinginan atau ketertarikan terhadap sesuatu, situasi tekanan yang dapat mengancam dirinya, keadaan fisik, psikis, emosional, dan pengalamannya, tingkat kecerdasan yang dimiliki, lingkungan sekitar, lemahnya minat dan motivasi pada pelajaran, perasaan gelisah, tertekan, marah, kuatir, takut, benci dan dendam, suasana lingkungan belajar yang berisik dan berantakan kondisi kesehatan, bersifat pasif dalam belajar, tidak memiliki kecakapan dalam cara-cara belajar baik (Hasminidiarty, 2015). Konsentrasi juga dapat dikatakan sebagai rangkaian usaha untuk memberikan kondisi tertentu agar seseorang mau dan mau melakukan sesuatu, jika tidak menyukainya maka ia akan berusaha untuk menyangkal atau menghindari perasaan tidak suka. Konsentrasi sebagai penggerak keseluruhan kegiatan belajar siswa, menjamin kelangsungan proses pembelajaran, memberikan arah bagi proses pembelajaran, memungkinkan tercapainya tujuan mata pelajaran pembelajaran, dan memungkinkan siswa mencapai pembelajaran di sekolah (Gujarati \& Porter, 2010).

Pentingnya konsentrasi dapat membuat siswa lebih menguasai materi yang diberikan dan menambah semangat serta motivasi untuk lebih aktif pada saat proses belajar dan mengajar berlangsung. Konsentrasi berpengaruh besar terhadap keberhasilan proses belajar mengajar, apabila seseorang mengalami kesulitan konsentrasi maka proses belajar mengajar menjadi tidak maksimal. Ini akan membuang waktu, tenaga dan uang. Ciri-ciri seseorang yang tidak konsentrasi antara lain sering bosan terhadap suatu hal, selalu berpindah tempat, tidak mendengarkan ketika diajak berbicara, mengalihkan pembicaraan, sering mengobrol, dan mengganggu teman lainnya (Winata, 2021).

Seorang siswa yang memliki disiplin belajar yang baik akan mempunyai kecakapan mengenai cara belajar. Hasil ini sangat diperlukan guna tercapainya hasil, sebab berhasil tidaknya siswa dalam usahanya pada dasarnya tergantung pada bagaimana ia melakukan cara-cara belajar yang baik. Prestasi belajar adalah perubahan tingkah laku yang diharapkan pada siswa setelah dilakukan proses mengajar (Fatimah et al., 2019). Prestasi akademik merupakan suatu hasil yang dapat dicapai selama berlangsungnya proses belajar mengajar dalam jangka waktu tertentu. Pada umumnya, prestasi belajar dalam sekolah dapat berupa pemberian nilai (angka) dari guru kepada siswa sebagai indikasi sejauh mana siswa telah menguasai materi pembelajaran yang telah disampaikan. Prestasi belajar yang dinyatakan dengan angka, huruf, atau kalimat yang terdapat dalam periode tertentu, dalam proses pembelajaran, konsentrasi memiliki pengaruh terhadap prestasi belajar, apalagi pada masa sekarang yang mana sedang diliputi oleh pandemi Covid-19 (Mayasari, 2017).

Penting bagi guru untuk memperhatikan berbagai macam strategi dalam kegiatan proses belajar mengajar guna memotivasi siswa serta untuk memusatkan perhatiannya pada setiap materi yang diberikan. Adanya wabah pandemi Covid-19 mengharuskan seluruh guru untuk bisa mengelola siswa dalam pemberian pembelajaran yang efektif. Walaupun hanya melalui pemberian tugas dan hanya belajar dari rumah, tetapi guru harus bisa membuat siswa mampu berkonsentrasi dalam belajar agar bisa memperoleh prestasi belajar walaupun pada masa pandemi Covid-19. Pandemi Covid-19 merupakan peristiwa menyebarnya penyakit Coronavirus disease 2019, yang kemudian disingkat COVID-19. Wabah ini menyebar di seluruh dunia, tanpa terkecuali dan bersifat menular.

Berlandaskan observasi yang dilakukan, di SDN Karang Mekar 4 Banjarmasin, masih banyak siswa yang kurang memperhatikan pelajaran yang telah diberikan guru karena pada masa pandemi Covid-19 siswa hanya diberikan tugas sehingga belajarnya dirumah sehingga siswa mengerjakan pembelajarannya sesuka hatinya ini disebabkan banyaknya siswa yang tidak berkonsentrasi dalam belajar.

Ada banyak faktor yang mempengaruhi prestasi belajar menurut oleh para ahli. Suryabrata (2009:233) mengungkapkan bahwa prestasi belajar dapat dipengaruhi oleh: faktor non-sosial yang meliputi udara, suhu, cuaca, waktu, dan lokasi; faktor sosial yang meliputi pengaruh mahasiswa di sekitar siswa; faktor fisiologis atau kondisi fisik; dan faktor psikologis atau kondisi kejiwaan. Sementara Ahmadi (2010:63-68) berpendapat bahwa presatsi belajar dipengaruhi oleh kemampuan yang sifatnya genetis, kondisi fisik, kondisi psikis, 
2308 Hubungan Konsentrasi Belajar Siswa terhadap Prestasi Belajar Peserta Didik pada Masa Pandemi Covid19 di Sekolah Dasar - Riinawati

DOI: https://doi.org/10.31004/edukatif.v3i4.886

kemauan belajar, sikap terhadap pengajar, ketersediaannya pembimbing, serta adanya evaluasi atau ulangan (Anggresta, 2016).

Ahmad Susanto (2013: 5) menyatakan hasil belajar adalah perubahan-perubahan yang terjadi pada diri siswa, baik yang menyangkut aspek kognitif, afektif dan psikomotorik sebagai hasil dari kegiatan belajar. Hal yang sama juga dikemukakan oleh Abdurrahman dalam Asep Jihad dan Abdul Haris (2012 : 14) hasil belajar adalah kemampuan yang diperoleh anak setelah belajar. Menurut Bejamin S. Bloom tiga ranah (domain) hasil belajar yaitu kognitif, afektif dan psikomotorik. Dari pendapat diatas dapat disimpulkan bahwa hasil belajar adalah kemampuan yang diperoleh anak setelah melalui kegiatan belajar. Karena belajar merupakan suatu bentuk perubahan perilaku yang relatif menetap dari ranah kognitif, afektif dan psikomotorik dari proses belajar yang dilakukan dalam waktu tertentu. Slameto mengemukakan bahwa (2013 : 54-60) faktor yang mempengaruhi hasil belajar adalah faktor intern yang bersumber dari dalam diri individu dan faktor ekstern adalah faktor yang ada di luar individu (Setiani et al., 2014).

Berdasarkan uraian diatas, peneliti tertarik untuk melakukan penelitian dengan judul Hubungan Konsentrasi Belajar Siswa Terhadap Prestasi Belajar Peserta Didik Pada Masa Pandemi Covid-19 di SDN Karang Mekar 4 Banjarmasin. Tujuan penelitian ini yaitu untuk mengetahui ada tidaknya hubungan konsentrasi belajar dengan prestasi belajar peserta didik pada masa pandemi covid-19 di SDN Karang Mekar 4 Banjarmasin.

\section{METODE PENELITIAN}

Penelitian ini dilakukan di SDN Karang Mekar 4 Banjarmasin yang beralamat dijalan Ahmad Yani KM. 3,5 Karang Paci Rt.04 No. 77, Kelurahan Karang Mekar, Kecamatan Banjarmasin Timur, Kota Banjarmasin dengan siswa-siswi SDN Karang Mekar 4 Banjarmasin sebagai subjek penelitian. Dalam penelitian ini yang dijadikan objek penelitian adalah Hubungan Konsentrasi Belajar Dengan Prestasi Belajar Peserta Didik pada masa Pandemi Covid-19 Di SDN Karang Mekar 4 Banjarmasin.

Populasi adalah keseluruhan subjek penelitian apabila seseorang ingin meneliti semua elemen yang ada dalam wilayah penelitian, maka penelitiannya merupakan penelitian populasi (Arikunto,S, 2019:173). Populasi dalam penelitian ini adalah siswa siswi SDN Karang Mekar 4 Banjarmasin, untuk keterangan lebih jelas dilihat pada tabel berikut :

Tabel 1

\begin{tabular}{|c|c|c|}
\hline \multirow[b]{2}{*}{ No } & \multicolumn{2}{|c|}{$\begin{array}{c}\text { Siswa-Siswi SDN Karang Mekar } 4 \\
\text { Banjarmasin }\end{array}$} \\
\hline & Kelas & Jumlah \\
\hline 1 & Kelas 1 & 31 \\
\hline 2 & Kelas 2 & 30 \\
\hline 3 & Kelas 3 & 32 \\
\hline 4 & Kelas 4 & 26 \\
\hline 5 & Kelas 5 & 34 \\
\hline 6 & Kelas 6 & 31 \\
\hline
\end{tabular}

Sampel adalah sebagian atau wakil populasi yang diteliti (Arikunto,S, 2019:174). Menurut Sugiyono "Sampel adalah bagian dari jumlah karakteristik yang dimiliki oleh populasi tertentu". Sedangkan menurut Margono "sampel adalah sebagian atau wakil populasi yang diteliti dengan menggunakan cara-cara tertentu" (A. Di \& Palembang, n.d.). Teknik sampel yang digunakan dalam penelitian ini menggunakan purposive sampling yang artinya pengambilan sampel tersebut dilakukan dengan pertimbangan tertentu (Arikunto,S, 
2309 Hubungan Konsentrasi Belajar Siswa terhadap Prestasi Belajar Peserta Didik pada Masa Pandemi Covid19 di Sekolah Dasar - Riinawati

DOI: https://doi.org/10.31004/edukatif.v3i4.886

2019:183) (Oliver, 2013). Sampel penelitian ini ditetapkan di kelas III di SDN Karang Mekar 4 Banjarmasin, Kelas III dengan jumlah 32 siswa. Peneliti memilih satu kelas tersebut karena mewakili kelas rendah untuk mengetahui apakah konsentrasi belajar siswa terhadap prestasi belajar peserta didik pada masa pandemi covid19. Peneliti juga mempertimbangkan efisiensi waktu agar para wali kelas tidak terganggu karena kehadiran peneliti, Jadi yang diambil hanya satu kelas. Sedangkan metode penelitian pada penelitian ini menggunakan deskripsi korelasi, penelitian korelasi adalah penelitian yang dilakukan oleh peneliti untuk mengetahui tingkat hubungan antara dua variabel atau lebih, tanpa melakukan perubahan, tambahan atau manipulasi terhadap data yang memang sudah ada (Sugiyono, 2017).

Sementara itu, alat penggali data yang digunakan peneliti dalam memperoleh data ini menggunakan alat penggali data yaitu angket dan dokumentasi. Uji coba penggalian data dilakukan dengan uji validitas dan realibilitas agar semua pertanyaan dalam angket valid. Untuk mengukur validitas angket yang diuji coba, maka dalam mengukur tingkat validitas peneliti menggunakan teknik korelasi Product Moment, yaitu sebagai berikut :

$$
\begin{aligned}
& r_{X Y}=\frac{n \sum X Y-\left(\sum X\right)\left(\sum Y\right)}{n} \\
& \sqrt{n \sum X^{2}-\left(\sum X^{2}\right) \sqrt{n \sum Y^{2}-\left(\sum Y\right)^{2}}}
\end{aligned}
$$

Sedangkan untuk uji reliabilitas dilakukan dengan teknik belah dua (Split Half), dimana hasil perhitungan korelasi itu dimasukkan dalam rumus yang menggunakan rumus Spearman Brown, sebagai berikut :

$$
\begin{aligned}
r_{11}= & 2 \times r^{1 / 2^{1 / 2}} \\
& 1+r^{1 / 2^{1 / 2}}
\end{aligned}
$$

Penelitian ini bertujuan untuk mengingat hubungan konsentrasi belajar terhadap prestasi belajar peserta didik pada masa pandemi covid -19. Konsentrasi belajar merupakan gejala internal dan prestasi belajar peserta didik pada masa pandemi Covid -19 adalah gejala ordinal. Mengungkapkan jika gejala yang satu berskala ordinal dan yang satu lagi berhubungan interval, perhitungan korelasinya menggunakan teknik korelasi serial, dengan rumus sebagai berikut :

$$
\begin{aligned}
r_{\text {ser }}= & \sum\{(\text { or }-o t)(M)\} \\
& \text { SDtot. } \sum\left\{\frac{(o r-o t)^{2}}{p}\right\}
\end{aligned}
$$

\section{HASIL DAN PEMBAHASAN PENELITIAN}

Setelah diketahui bahwa angket yang digunakan valid dan reliabel, maka angket dapat disebarkan kepada sampel penelitian yaitu siswa kelas III Sekolah Dasar Negeri Karang Mekar 4 Banjarmasin yang berjumlah 32 orang siswa pada tanggal 13 Maret 2021 pada saat pandemi Covid-19 disebarkan melalui tatap muka siswa dikumpulkan dalam satu kelas dengan hanya 50\% (16 siswa) di hari yang sama dan dilanjutkan dihari yang sama dengan pukul waktu yang berbeda 50\% (16 siswa) nya dengan menjaga protokol kesehatan ketat saat penyebaran seperti menggunakan masker, penyedian handsanitezer, cuci tangan, dan menjaga jarak. Setelah data terkumpul, kemudian data tersebut akan dianalisis yaitu sebagai berikut :

a. Data tentang Konsentrasi Belajar

Untuk memperoleh data tentang konsentrasi belajar, peneliti menyebarkan angket kepada responden yaitu siswa kelas III di Sekolah Dasar Karang Mekar 4 Banjarmasin. Setelah angket disebarkan kepada 32 orang siswa selanjutnya didapatkan hasil jawaban angket konsentrasi belajar siswa. Dari data tersebut diketahui luas intervalnya adalah 7 yang nantinya akan diketahui kualitas masing-masing konsentrasi belajar berdasarkan kategori. 
2310 Hubungan Konsentrasi Belajar Siswa terhadap Prestasi Belajar Peserta Didik pada Masa Pandemi Covid19 di Sekolah Dasar - Riinawati

DOI: https://doi.org/10.31004/edukatif.v3i4.886

Tabel 2 Interval Konsentrasi Belajar Siswa

\begin{tabular}{cc}
\hline Interval & Kategori \\
\hline $55-48$ & Tinggi \\
\hline $47-40$ & Sedang \\
\hline $39-33$ & Rendah \\
\hline
\end{tabular}

Selanjutnya didapatkan rata-rata konsentrasi belajar siswa kelas III di Sekolah Dasar Negeri Karang Mekar 4 Banjarmasin pada kategori Tinggi. karena MX = 49,625 berada pada interval 55-48. dengan demikian dapat disimpulkan bahwa secara umum rata-rata kualitas konsentrasi belajar siswa pada taraf tinggi dalam proses pembelajaran di Sekolah Dasar Negeri Karang Mekar 4 Banjarmasin.

b. Data tentang Prestasi Belajar Siswa

Prestasi tersebut diperoleh dari nilai semester ganjil tahun pelajaran 2020/2021 dari masing-masing siswa. Dari data tersebut diketahui skor tertinggi $(\mathrm{H})$ adalah 84,3dan skor terendah $(\mathrm{L})$ adalah 75,0 jadi $\mathrm{R}=$ $84,3-75,0=9,3$. Kemudian diketahui luas intervalnya adalah 3,1.

Tabel 3 Interval Nilai Prestasi Belajar Siswa

\begin{tabular}{cc}
\hline Interval & Kategori \\
\hline $84,3-81,2$ & Baik \\
\hline $81,1-78,1$ & Cukup Baik \\
\hline $78,0-75,0$ & Kurang Baik \\
\hline
\end{tabular}

Telah diketahui bahwa jumlah nilai prestasi belajar siswa pada kelas III $\left(\sum y\right)$ adalah 2.587 dan jumlah siswa (F) adalah 32 orang, maka didapat rata - rata Prestasi Belajar Peserta Didik berada pada kategori baik, karena $\mathrm{M}=80,8$ berada pada interval $81,1-78,1$. Disimpulkan dengan demikian dapat bahwa secara umum rata - rata prestasi belajar peserta didik kelas III diSekolah Dasar Negeri Karang Mekar 4 Banjarmasin tergolong Cukup Baik.

c. Hubungan Konsentrasi Belajar dengan Prestasi Belajar

Berdasarkan pada hipotesis dalam penelitian ini maka analisis yang dilakukan untuk mengetahui Hubungan Konsentrasi Belajar dengan Prestasi Belajar Peseta Didik di Sekolah Dasar Negeri Karang Mekar 4 Banjarmasin, maka dilakukan perhitungan rumus korelasi serial dan mendapat data Standar Deviasi Total (SDtot) yaitu sebesar 25,04 dan Indeks Korelasi Serial sebesar 0,836. Hubungan untuk mengetahui konsentrasi belajar dengan prestasi belajar peserta didik di Sekolah Negeri Karang Mekar 4 Banjarmasin, maka nilai koefisien dikonsultasikan dengan tabel $\mathrm{r}$ product moment. Nilai koefisien korelasi serial yang didapat adalah 0,836 jika dikonsultasikan dengan tabel $\mathrm{r}$ product moment dengan taraf signifikan $5 \%$ yaitu 0,349 dan 0,449 .

Perbandingan dimana didapat dari $r_{-}$ser dan $r_{-}$tabel product moment yaitu :

1. Dengan taraf signifikan $1 \%$ r_ser $>$ r_tabel yaitu $0,836>0,449$

2. Dengan taraf signifikan 5\% r_ser>r_tabel yaitu 0,836>0,349

Maka demikian, menggunakan taraf signifikan 5\% dapat disimpulkan bahwa hipotesis alternatif (Ha) yang berbunyi ada hubungan yang signifikan antara konsentrasi belajar terhadap prestasi belajar peserta didik pada masa pandemi Covid-19 di Sekolah Karang Mekar 4 Banjarmasin "diterima” dan hipotesis nol (Ho) yang berbunyi tidak ada hubungan yang signifikan antara konsentrasi belajar dengan prestasi belajar peserta didikpada masa pandemi covid-19 di Sekolah Karang Mekar 4 Banjarmasin "ditolak".

Berdasarkan hasil analisis data tersebut diperoleh r_hitung lebih besar dari r_tabel product moment. Hal ini berarti konsentrasi belajar sangat berhubungan erat terhadap prestasi belajar peserta didik pada masa pandemi covid-19 diSekolah Karang Mekar 4 Banjarmasin, terbukti dengan siswa yang berkonsentrasi belajarnya cukup baik prestasi belajarnyanya lebih baik. 
2311 Hubungan Konsentrasi Belajar Siswa terhadap Prestasi Belajar Peserta Didik pada Masa Pandemi Covid19 di Sekolah Dasar - Riinawati

DOI: https://doi.org/10.31004/edukatif.v3i4.886

Konsetrasi bukanlah sifat bawaan yang dimiliki seseorang, melainkan merupakan suatu kemampuan untuk memfokuskan dan menjaga pikiran terhadap suatu hal. Konsentrasi belajar siswa dipengaruhi dari kemampuan otak masing-masing siswa untuk memusatkan perhatian pada apa yang sedang dipelajari. Pemusatan perhatian ini untuk meningkatkan kemungkinan siswa dapat menyerap dan memahami informasi yang didapat. Menurut seorang ilmuwan ahli psikologis yang tidak disebutkan namanya dalam Hamiyah dan Jauhar (2014: 103), kekuatan belajar seseorang setelah 30 menit telah mengalami penurunan (Setyani \& Ismah, 2018). Fokus yang ditajamkan meningkatkan kemungkinan seseorang dapat menyerap dan memahami informasi yang tepat. Prestasi yang didapat oleh siswa tidak terlepas dari konsentrasi belajar siswa didalam proses belajar, maka dapat disimpulkan bahwa konsentrasi belajar besar pengaruhnya terhadap prestasi belajar. Seseorang mengalami kesulitan berkonsentrasi, jelas belajarnya akan sia-sia, karena seseorang yang dapat belajar harus mampu berkonsentrasi dengan baik. Kata lain ia harus mampu memiliki kebiasaan untuk memusatkan pikiran, jadi kebiasaan untuk bisa belajar dengan fokus ini mutlak untuk dimiliki oleh setiap siswa yang belajar, sehingga dapat dipastikan bahwa konsentrasi belajar yang baik dapat meningkatkan prestasi belajar peserta didik. Terbukti hal tersebut pada analisis data, siswa yang berkonsentrasi belajarnya baik prestasinya lebih baik dibandingkan dengan siswa yang berkonsentrasi belajarnya kurang baik. Prestasi belajar peserta didik dipengaruhi oleh dua faktor yaitu eksternal dan internal konsentrasi belajar merupakan bagian dari faktor internal yang berasal dari dalam diri siswa. Dengan konsentrasi belajar yang baik siswa dapat menyerap dan memahami informasi yang didapat saat siswa belajar.

\section{KESIMPULAN}

Berdasarkan data-data yang telah dikumpulkan dari hasil penelitian yang dilakukan sebagaiman telah diuraikan pada bab terdahulu, maka dapat ditarik kesimpulan sebagai berikut :

1. Konsentrasi belajar siswa pada masa pandemi covid-19 di Sekolah Karang Mekar 4 Banjarmasin, berada pada kategori Tinggi interval 55-48 dengan nilai rata-rata 49,625

2. Prestasi belajar peserta didik pada masa pandemi covid-19 di Sekolah Karang Mekar 4 Banjarmasin, berada pada kategori cukup baik, interval $81,1-78,1$ dengan nilai rata-rata 80,8

3. Berdasarkan analisis data yang menunjukan bahwa r_ser sebesar 0,836, dan r_tabel sebesar 0,349 dengan taraf signifikan 5\%. Maka demikian telah terbukti kebenaran hipotesis alternatif (Ha) yang berbunyi "Ada hubungan yang signifikan antara konsentrasi belajar dengan prestasi belajar peserta didik pada masa pandemi covid-19 di Sekolah Dasar Negeri Karang Mekar 4 Banjarmasin "diterima" dan Hipotesis nol (Ho) yang berbunyi : "Tidak ada hubungan konsentrasi belajar siswa dengan prestasi belajar peserta didik pada masa pandemi covid-19 di Sekolah Dasar Negeri Karang Mekar 4 Banjarmasin "ditolak".

\section{UCAPAN TERIMA KASIH}

Jika perlu berterima kasih kepada pihak tertentu, misalnya sponsor penelitian, nyatakan dengan jelas dan singkat, hindari pernyataan terima kasih yang berbunga-bunga.

\section{DAFTAR PUSTAKA}

Andari Susilowati. (2009). Pengaruh Motivasi. Minat Dan Lingkungan Belajar Terhadap Prestasi Belajar Mahasiswa Akafarma Sunan Giri Ponorogo. Jurnal UPT UNNES.

Anggresta, V. (2016). Analisis Faktor-Faktor Yang Mempengaruhi Prestasi Universitas Negeri Padang Vella Anggresta Email : Vellaanggresta@Yahoo.Com PENDAHULUAN Memasuki Abad Ke-21 Sekarang Ini , Pendidikan Indonesia Dihadapkan Dengan Sejumlah Tantangan Dan Peluang, Yang Tentun. Journal 
2312 Hubungan Konsentrasi Belajar Siswa terhadap Prestasi Belajar Peserta Didik pada Masa Pandemi Covid19 di Sekolah Dasar - Riinawati

DOI: https://doi.org/10.31004/edukatif.v3i4.886

Of Economic And Economic Education Vol.4 No.1 (19-29) ANALISIS, 4(1), 19-29.

Aviana, R., \& Hidayah, F. (2015). Pengaruh Tingkat Konsentrasi Belajar Siswa Terhadap Daya Pemahaman Materi Pada Pembelajaran Kimia Di Sma Negeri 2 Batang. Jurnal Pendidikan Sains Universitas Muhammadiyah Semarang, 3(1), 30-33. Https://Doi.Org/10.26714/Jps.3.1.2015.30-33

Balinda, Prasetyo, Julianto, Dzulqaidah, \& Salsabilah, 2014. (2014). "Apakah Faktor Faktor Yang Mempengaruhi Konsentrasi Belajar Pada Mahasiswa Program Studi Ilmu Keperawatan Universitas Muhammadiyah Yogyakarta." 1-6.

Di, A., \& Palembang, M. A. N. (N.D.). 3010-Article Text-7817-2-10-20190121. 13, 1-20.

Di, B., Negeri, S. M. P., \& Lampung, B. (2015). Mengikuti Bimbingan Belajar Dengan Yang Tidak Mengikuti Bimbingan. 2(1), 53-58.

Fatimah, S., Nurbaeti, R. U., \& Pranoto, B. A. (2019). Hubungan Antara Disiplin Dan Motivasi Dengan Prestasi Belajar Siswa Kelas III. Jurnal Ilmiah Kontekstual, 01(1), 63-69. Http://Jurnal.Umus.Ac.Id/Index.Php/Kontekstual/Article/View/60

Gujarati， D., \& Porter， D. (2010). No 主観的健康感を中心とした在宅高齢者における 健康関連指標に関する共分散構造分析Title. 0-7.

Hasminidiarty. (2015). Faktor-Faktor Yang Berkaitan Dengan Prestasi Belajar Mahasiswa Hasminidiarty 1. Ilmiah, Jurnal Batanghari, Universitas Vol, Jambi, 15(3), 96-110.

Ikbal, B., Sutria, E., \& Hidayah, N. (2017). Pengaruh Senam Otak Terhadap Konsentrasi Belajar Mahasiswa Keperawatan Uin Alauddin Makassar Bilwalidayni. 2, 52-59.

Juita. (2020). Identifikasi Konsentrasi Belajar Siswa Di Sekolah Menengah Atas. Journal Of Physics Educationhysics Education, 1(1), 24-29. Https://Cahaya-Ic.Com/Index.Php/SJPE

Masalah, A. L. B. (2008). Departemen Agama RI, Al-Hikmah: Al- Qur'an Dan Terjemah, (Bandung: Diponegoro, 2008) 1. 1-29.

Mayasari, F. (2017). Pengaruh Konsentrasi Belajar Terhadap Hasil Belajar Siswa. Universitas Tanjung Pura, $1-11$.

Nasional, U. S. P. (1982). Introduction And Aim Of The Study. Acta Padiatrica, 71, 6-6. Https://Doi.Org/10.1111/J.1651-2227.1982.Tb08455.X

Navia, Y., \& Yulia, P. (2017). Hubungan Disiplin Belajar Dan Konsentrasi Belajar Terhadap Hasil Belajar Matematika Siswa. PYTHAGORAS: Jurnal Program Studi Pendidikan Matematika, 6(2), 100-105. Https://Doi.Org/10.33373/Pythagoras.V6i2.905

Oliver, J. (2013). Jenis-Jenis Pendekatan. Journal Of Chemical Information And Modeling, 53(9), 1689-1699.

Setiani, A. C., Setyowani, N., Kurniawan, K., Bimbingan, J., \& Konseling, D. (2014). Indonesian Journal Of Guidance And Counseling: Theory And Application Meningkatkan Konsentrasi Belajar Melalui Layanan Bimbingan Kelompok. Indonesian Journal Of Guidance And Counseling: Theory And Application, 3(1), 37-42. Http://Journal.Unnes.Ac.Id/Sju/Index.Php/Jbk

Setyani, M. R., \& Ismah. (2018). Analisis Tingkat Konsentrasi Belajar Siswa Dalam Proses Pembelajaran Matematika Ditinjau Dari Hasil Belajar. Pendidikan Matematika, 01, 73-84.

Sugiyono. (2017). Prof. Dr. Sugiyono, Metode Penelitian Kuantitatif Kualitatif Dan R\&D. Intro ( Pdfdrive.Com ).Pdf.

Winata, I. K. (2021). Konsentrasi Dan Motivasi Belajar Siswa Terhadap Pembelajaran Online Selama Masa Pandemi Covid-19. Jurnal Komunikasi Pendidikan, 5(1), 13. Https://Doi.Org/10.32585/Jkp.V5i1.1062 